\title{
地球温暖化による沿岸外力の変化を考慮した 消波ブロック被覆堤の最適設計
}

\section{Optimum Design of Armoured Breakwater with Blocks Considering Climate Change Effects}

\author{
辻尾大樹 $^{1}$ ・間瀬 肇 $^{2} \cdot$ 森 信人 $^{3} \cdot$ 安田誠宏 $^{4}$
}

\author{
Daiki TSUJIO, Hajime MASE, Nobuhito MORI and Tomohiro YASUDA
}

\begin{abstract}
This study proposes an optimum design method of caisson type breakwater covered with concrete blocks considering the effects of climate change on coastal environment, such as changes in the sea level, storm surge and wave height. Life cycle cost (LCC) of armoured breakwater in the future condition becomes smaller if heavier blocks than necessity weight estimated by an empirical formula are employed for the case that its design wave height is smaller than $8 \mathrm{~m}$ in the present study conditions. In LCC evaluation, economic indicators, such as the social discount and GDP, are considered. Although LCC and optimum specifications of breakwaters will change due to the external forces, the proposed design method is generally applicable by employing the latest reliable future climate projections.
\end{abstract}

\section{1.はじめに}

近年，気候変動や地球温暖化に伴う海面上昇や台風の 強大化等の影響が指摘されている. 海岸, 港湾構造物に 対して重要となるのは, 地球温暖化によって長期的に変 化する沿岸外力であり, 海面上昇による平均水深の変化, 台風の強大化等による高潮や波浪の変化が挙げられる. これらの変化は, 海岸構造物の安定性, 低平地の浸水被 害，および海浜地形に影響を与えると考えられる。 その ため, 地球温暖化に伴う気象・海象条件の変化に対する 沿岸災害評価の一連の研究が進められており，これに対 応した海岸・港湾構造物の安定性を照査することが重要 な課題となる.

2007年に改訂された「港湾の施設の技術上の基準・同 解説」（(社) 日本港湾協会，2007）では, 性能設計が採 用された。こうした背景のもと，設計波としての50年確 率波だけではなく，設計供用期間に発生する高波浪を対 象として，変形量を考慮した防波堤の設計法の確立に向 けた研究が進められてきた。地球温暖化に伴う沿岸外力 の変化は考慮していないが，一般的な消波ブロック被覆 堤の滑動量を考慮した設計法における既往の研究とし て，下迫ら（2006）は，下迫・高橋（1998）の混成堤の 滑動量算定手法を消波ブロック被覆堤に拡張し, 実海域 の構造物設計を行った。また，高山ら（2007）は，下迫 ら（2006）では考慮されていなかった設計供用期間中の 消波ブロックの被災を考慮し，不完全被覆による波圧増

\begin{tabular}{lllll}
\hline & 正会員 & 博(工) & \multicolumn{2}{c}{ パシフィックコンサルタンツ (株) } \\
2 & 正会員 & 工博 & 京都大学教授 & 防災研究所 \\
3 & 正会員 & 博(工) & 京都大学准教授 & 防災研究所 \\
4 & 正会員 & 博(工) & 京都大学助教 & 防災研究所
\end{tabular}

大を考慮した滑動量算出法を提案している。一方，地球 温暖化による外力変化を考慮して，防波堤の安定性を検 討した例がいくつかある（例えば，酒井・岡安，2004）. しかし, 将来変化の設定は最近の気候変動予測に基づく ものではなく，想定した将来変化を仮に与えているだけ であった。また，現在から将来への経年的な変化は考慮 されておらず，現在と将来の状態のみを対象とした検討 であり, 設計で重要となる台風による高潮偏差の変化も 考慮されていない. また，これまでの防波堤のライフサ イクルコスト（以下，LCCと略す）の最小化手法に関す る研究においては, 供用期間中の地球温暖化等の外力の 長期変化は考慮されていない.

そこで, 本研究では, 地球温暖化に伴って漸近的に変 化すると予測される供用期間内の沿岸外力の変化を考慮 して, 消波ブロック被覆堤の滑動量を解析し, 消波ブロ ックの補修費を算出して, 外力特性の変化を考慮した消 波ブロック被覆堤の最適設計法を提案する.さらに， LCCの算定に経済指標を導入し，その影響度についても 評価する.

\section{2. 検討対象外力と解析手法}

\section{(1) 対象外力}

防波堤の滑動安定性に影響を及ぼす沿岸外力要因は 様々あるが, 本研究では, a）地球温暖化に伴う海面上 昇，b）台風の強大化等に伴う高潮偏差，c）台風の強大 化等に伴う来襲波浪を対象とする。計算条件は, 过尾ら （2012）と同様であり，その計算結果の一部を用いた.

\section{a) 海面上昇}

2007 年に発表された気候変動に関する政府間パネル （IPCC，2007）の第4次報告書では， $\mathrm{CO}_{2}$ 排出シナリオ 
（SRES）として6種類のシナリオを想定しており，それ ぞれに対する気温変化のアンサンブル推定值と予測幅, および海面水位上昇の予測幅が報告されている. 今世紀 末の海面水位に関しては, 最低でも $0.18 \mathrm{~m}$, 最大で 0.59 $\mathrm{m}$ 上昇すると予測されている.

森ら（2011）は, 図-1に示すように, CMIP3の結果 （SRES A1B）をもとに, シナリオ・モデル・アンサンブ ル平均として日本近海の海面水位の将来変化を（0.26 $\mathrm{m} / 100$ 年) を計算している. 本研究ではこれを設定条件 として採用する.

\section{b) 高潮偏差の増大}

高潮偏差の将来変化については, 高波の条件と同一の 気候変動の条件から考えることが望ましいが, 高潮は高 波よりも台風の経路に鋭敏に依存するため, 決定論的に 将来変化を推定することは難しい（Mori，2012）.

このような気候変動に従う台風特性の変化に伴う高潮 の変化については, いくつか検討されている（例えば, 河合ら, 2007 ; 安田ら, 2011). 河合ら（2007）は, 橋 本ら（2005）が, SRES A2シナリオの領域気候モデルの 計算結果に基づいて示した, 将来気候下に扔ける日本周 辺の台風特性の変化に準じて, 高潮がどのように変化す るかを検討している，海面上昇と比べて, 高潮の将来変 化予測の不確実性は大きく, 地域に大きく依存するが, 本研究では, 高潮の将来変化の 1 つの可能性として, 河 合らが予測した大阪港での極值分布（図-2）を採用した.

\section{c）来襲波浪の増大}

気候変動による台風の強大化, 極端化によって変化す る来襲波浪特性について, 森ら（2010）は, SRES A1B シナリオに基づく全球気候モデル GCMによる気候変動 予測実験結果（Kitohら，2009）をもとに，現在から今 世紀末の全球に扔ける風速場や波浪場の将来変化予測を 行った。波浪解析には $\mathrm{GCM}$ の海上風を外力としてスぺ クトル型波浪モデルを用いて予測計算を行い, 図-3に示 す $\mathrm{I} \sim \mathrm{IV}$ の領域に対して, 現在と将来の極值分布の変化 を示している.

本研究では, 来襲波浪として, 森らの現在気候（1979 ～2003 年）と今世紀末（2075～2099年）の波浪解析值 から得た領域II とIIIの極大值分布を用いた。なお，周期 は波形勾配が一定にあるように与えた。森らの結果は, 一年を夏季と冬季に分けた極大值資料に基づく極值分布 であるので, それぞれの季節における年平均発生数 $\lambda_{j}$ を 求めた上で年最大值分布を次式で求めた。

$$
F(x)=\exp \left\{-\sum_{j=1}^{n} \lambda_{j}\left[1-F_{j}(x)\right]\right\}
$$

ここに, $F(x)$ : 年最大值分布の発生確率 $x$ の確率值, $F_{j}$ $(x): j$ 番目の極大值分布の発生確率 $x$ の確率值, $n:$ 極大

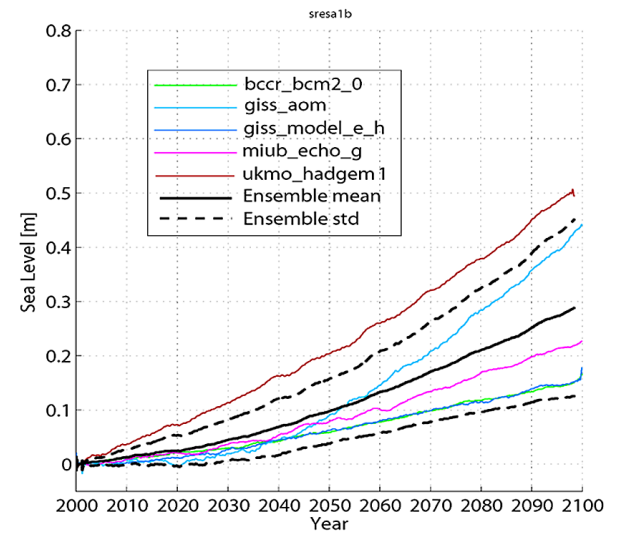

図-1 日本近海の海面上昇の予測值：SRES A1B（森ら，2011） (黒実線：モデル平均, 黒破線：平均 + 標準偏差, その 他：各 GCM の結果)

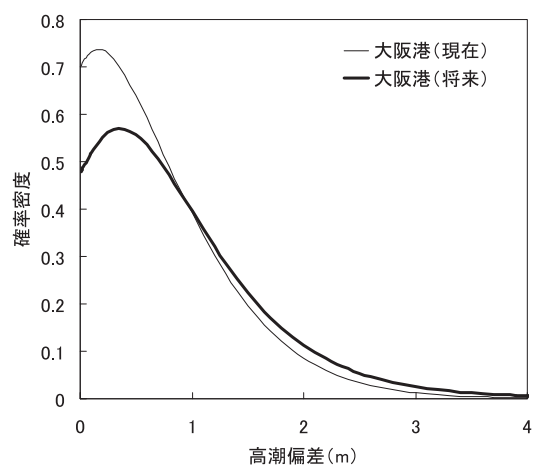

図-2 現在と将来の大阪港での高潮偏差の極值分布（河合ら， 2007)

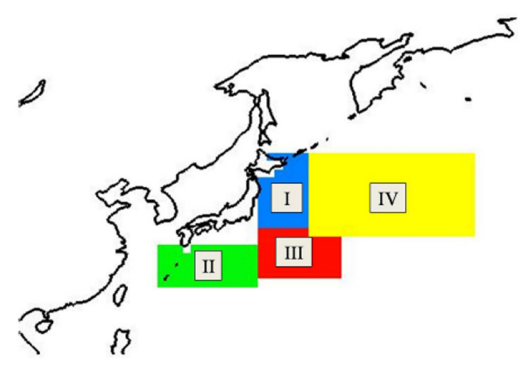

図-3 波浪の極值統計解析の対象領域（森ら, 2010）

值分布の数, $\lambda_{j}$ : 各季の極大值分布に対応する年平均発 生数である. 森ら（2010）はそれぞれの領域に対して夏 季（6ケ月）と冬季（6ケ月）の極值分布を求めているた

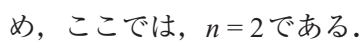

\section{（2）外力変化の考慮方法}

設計供用期間中の外力は, 基本的に線形増大すると仮 定する。海面上昇については, モデルアンサンブルから 平均值として $0.26 \mathrm{~m} / 100$ 年の上昇が予測されているため, 検討対象年に応じて, $0.0026 \mathrm{~m} /$ 年の海面上昇から L.W.L. を設定し, その上に天文潮位による水位変化を考慮した。 
ここで，天文潮位は将来変化しないと仮定している。ま た，現在気候と将来気候における極值分布から算定され る高潮偏差と沖波波浪は，次式のように，発生年次を考 慮して線形補完することで，その年に発生する高潮偏差 と沖波波浪を求めた。

$$
H(x)=H_{1}(x)+\frac{y}{Y}\left[H_{2}(x)-H_{1}(x)\right]
$$

ここに, $H(x)$ : 年最大值分布の発生確率 $x$ の確率值 $H_{1}$ $(x)$ : 現在の年最大值分布の発生確率 $x$ の確率值, $H_{2}(x)$ : 将来の年最大值分布の発生確率 $x$ の確率值, $Y$ : 将来の基 準年（本研究では 100 年後を対象としているため $Y=$ $100), y$ : 検討対象の経過年（発生年次）である.

\section{（3）解析手法, 条件}

設計供用期間中における防波堤の滑動量解析には，高 山ら（2007）の滑動量算定モデルを用いた。期待補修費 の算出には，辻尾・安田（2009）と同様に，算定した滑 動量から，滑動に伴うブロック沈下と波浪によるブロッ ク散乱に伴うブロック沈下を考慮して，ブロックの補修 費を算定した。計算条件は，日本近海領域IIを表-1に， 領域IIIを表-2に示す．各領域の堤体幅と天端高は，領域 II の 50 年確率波に対して，屈折係数 0.5 と 1.0 の 2 通りの 設計波を基に安全率が 1.2 となる断面とし，領域IIIに対 しても同様に屈折係数 0.3 と 0.5 の 2 通りを対象とした. 前面には $2 \mathrm{t} \sim 80 \mathrm{t}$ までの 16 種類の消波ブロックを設置 し，計算ケースとして，温暖化を考慮する場合と考慮し ない場合，さらに，消波ブロックを補修する場合と補修 しない場合を設定した。

また，既往研究において，社会的割引率（以下，SDR と略す) と GDPデフレータは考慮されていない例が多い. 設計供用期間中の補修費に，SDRとGDPデフレータによ る価值の変化を考慮し，その影響を調べておくことは， 最適設計に重要と考える。本研究では，SDRとGDPデフ レータによる最適 LCCの変化を検討するために，1） SDR，GDPデフレータ考慮無し，2）SDRのみ考慮，3） SDR と日本の GDPデフレータを考慮，3） SDRと中国の GDPデフレータを考慮，の計4ケースを設定し，現在価 值に換算して補修費を算出した。 SDRは，一般に公共事 業で用いられている4\%を適用したＧDPデフレータは 過去のものしか存在せず，GDP成長率を GDPデフレータ として，将来の価值変動を取り入れた。なお，デフレー 夕の将来予測は「長期経済予測（2006〜2050年)」（(社） 日本経済研究センター，2007）を採用した。設定した4ケ ースの経過年数に対する現在価值の変化を，図-4に示す.

\section{LCCの算出}

\section{（1）初期建設費}

まず，表-1の計算条件の下，辻尾ら（2012）が算出し
表-1 計算条件（領域 II）

\begin{tabular}{|c|c|c|c|}
\hline 項目 & \multicolumn{3}{|c|}{ 值 } \\
\hline $\begin{array}{l}\text { 沖波波浪 } \\
\text { (現在，夏) }\end{array}$ & \multicolumn{3}{|c|}{$\begin{array}{l}50 \text { 年確率波浪 } \quad 20.07 \mathrm{~m} \quad(\lambda=0.43) \\
\text { Weibull分布 } k=1.0, A=4.02, B=7.74\end{array}$} \\
\hline $\begin{array}{l}\text { 沖波波浪 } \\
\text { (現在，冬) }\end{array}$ & \multicolumn{3}{|c|}{$\begin{array}{c}\text { 50年確率波浪 } \quad 10.82 \mathrm{~m} \quad(\lambda=1.47) \\
\text { Weibull分布 } k=1.4, A=1.80, B=5.72\end{array}$} \\
\hline $\begin{array}{l}\text { 沖波波浪 } \\
\text { (将来，夏) }\end{array}$ & \multicolumn{3}{|c|}{$\begin{array}{c}50 \text { 年確率波浪 } \quad 24.79 \mathrm{~m} \quad(\lambda=0.53) \\
\text { Weibull分布 } k=1.0, A=5.25, B=7.58\end{array}$} \\
\hline $\begin{array}{l}\text { 沖波波浪 } \\
\text { (将来, 冬) }\end{array}$ & \multicolumn{3}{|c|}{$\begin{array}{c}50 \text { 年確率波浪 } \quad 10.84 \mathrm{~m} \quad(\lambda=0.91) \\
\text { Weibull分布 } k=1.0, A=1.26, B=6.03 \\
\end{array}$} \\
\hline 設置水深 $(h)$ & $7 \mathrm{~m}$ & $10 \mathrm{~m}$ & $15 \mathrm{~m}$ \\
\hline 堤体幅: $K_{r}=1.0$ & $16.8 \mathrm{~m}$ & $18.3 \mathrm{~m}$ & $21.3 \mathrm{~m}$ \\
\hline 堤体幅: $K_{r}=0.5$ & $14.3 \mathrm{~m}$ & $16.1 \mathrm{~m}$ & $19.3 \mathrm{~m}$ \\
\hline 天端高 : $K_{r}=1.0$ & $4.2 \mathrm{~m}$ & $5.2 \mathrm{~m}$ & $6.8 \mathrm{~m}$ \\
\hline 天端高： $K_{r}=0.5$ & $3.8 \mathrm{~m}$ & $4.8 \mathrm{~m}$ & $6.4 \mathrm{~m}$ \\
\hline 高潮偏差 & \multicolumn{3}{|c|}{$\begin{array}{c}\text { 50年確率偏差 } \quad 2.616 \mathrm{~m} \\
\text { Weibull分布 } k=1.4, A=0.998, B=-0.248\end{array}$} \\
\hline $\begin{array}{l}\text { 高潮偏差 } \\
\text { (将来) }\end{array}$ & \multicolumn{3}{|c|}{$\begin{array}{c}50 \text { 年確率偏差 } \quad 3.199 \mathrm{~m} \\
\text { Gumbel分布 } A=0.646, B=0.358\end{array}$} \\
\hline 水位上昇 & \multicolumn{3}{|c|}{$0.0026 \mathrm{~m} / \mathrm{yr} \quad(0.26 \mathrm{~m} / 100 \mathrm{yrs})$} \\
\hline 継続時間 & \multicolumn{3}{|c|}{ 2時間 } \\
\hline 設計供用期間 & \multicolumn{3}{|c|}{ 50年 } \\
\hline 繰返し回数 & \multicolumn{3}{|c|}{10,000 回 } \\
\hline 要補修被災度 & \multicolumn{3}{|c|}{ 全被覆面積の5\% } \\
\hline
\end{tabular}

表-2 計算条件（領域 III）

\begin{tabular}{|c|c|c|c|}
\hline $\begin{array}{l}\text { 項目 } \\
\end{array}$ & \multicolumn{3}{|c|}{ 值 } \\
\hline $\begin{array}{l}\text { 沖波波浪 } \\
\text { (現在，夏) }\end{array}$ & \multicolumn{3}{|c|}{$\begin{array}{l}50 \text { 年確率波浪 } \quad 13.1 \mathrm{~m} \quad(\lambda=0.14) \\
\text { Weibull分布 } k=1.4, A=3.42, B=7.63\end{array}$} \\
\hline $\begin{array}{l}\text { 沖波波浪 } \\
\text { (現在, 冬) }\end{array}$ & \multicolumn{3}{|c|}{$\begin{array}{l}50 \text { 年確率波浪 } \quad 12.3 \mathrm{~m} \quad(\lambda=0.77) \\
\text { Weibull分布 } k=1.0, A=1.42, B=7.12\end{array}$} \\
\hline $\begin{array}{l}\text { 沖波波浪 } \\
\text { (将来，夏) }\end{array}$ & \multicolumn{3}{|c|}{$\begin{array}{l}50 \text { 年確率波浪 } \quad 21.5 \mathrm{~m} \quad(\lambda=0.42) \\
\text { Weibull分布 } k=1.4, A=6.41, B=7.30\end{array}$} \\
\hline $\begin{array}{l}\text { 沖波波浪 } \\
\text { (将来, 冬) }\end{array}$ & \multicolumn{3}{|c|}{$\begin{array}{c}50 \text { 年確率波浪 } \quad 13.46 \mathrm{~m} \quad(\lambda=1.16) \\
\text { FT-II分布 } k=5.0, A=0.90, B=7.84\end{array}$} \\
\hline 設置水深 $(h)$ & $7 \mathrm{~m}$ & $10 \mathrm{~m}$ & $15 \mathrm{~m}$ \\
\hline 堤体幅: $K_{r}=0.5$ & $12.5 \mathrm{~m}$ & $14.1 \mathrm{~m}$ & $17.4 \mathrm{~m}$ \\
\hline 堤体幅 : $K_{r}=0.3$ & $12.0 \mathrm{~m}$ & $13.5 \mathrm{~m}$ & $13.8 \mathrm{~m}$ \\
\hline 天端高 : $K_{r}=0.5$ & $3.5 \mathrm{~m}$ & $4.5 \mathrm{~m}$ & $4.5 \mathrm{~m}$ \\
\hline 天端高： $K_{r}=0.3$ & $3.2 \mathrm{~m}$ & $3.2 \mathrm{~m}$ & $2.8 \mathrm{~m}$ \\
\hline
\end{tabular}

*高潮偏差以降の条件は表-1と同様である.

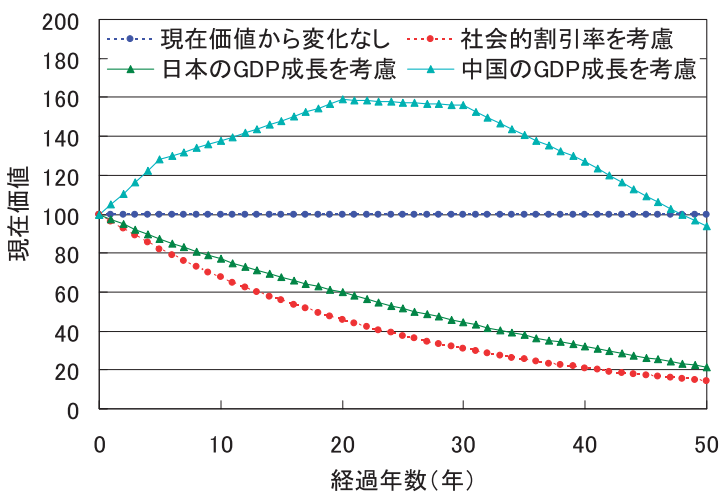

図-4 現在価值の変化（社会的割引率と GDPデフレータ） 
たブロック質量毎の必要堤体幅を用いて，それらに対す る初期建設費を算出した。 各ブロック質量に対する初期 建設費は図-5に示す通りである．なお，初期建設費の算 出には, ケーソン費用： 15 千円 $/ \mathrm{m}^{3}$, マウンド+被覆材費 用：18千円 $/ \mathrm{m}^{3}$ 等を用いた。 ブロック質量が大きくなる ほど，ケーソン幅が小さくなるため，ケーソン費用は安 くなるが，ブロック費用，マウンド被覆材費用は，ブロ ックが大きくなると, 大きくなる傾向がわかる，本ケー スでは，12 t型を用いた場合の初期建設費が最も安いこ とになる。

\section{（2）期待補修費}

次に，辻尾ら（2012）が算出した，設計供用期間中に 発生した滑動量およびブロック沈下量から，50年間の期 待補修費を算出した。その際，SDRやGDPデフレータの 考慮の有無で4ケースの期待補修費を算出した。図-6に 期待補修費の算出例を示す。本ケースでは社会的割引率 やGDPデフレータの設定の違いは，被害が大きいブロッ ク質量の小さい場合に顕著となり, 期待補修費の差は最 大で2〜3倍程度になった。

\section{(3) LCC}

（1）初期建設費に（2）期待補修費を加えて，各ブロッ ク質量を用いた場合のLCCを求めた。図-7にLCC の算出 例を示す．SDRやGDPデフレータの考慮の有無による期 待補修費の差は大きいが，LCCが最小となるような期待 補修費が小さい場合では，社会的割引率等の考慮方法に よる変化は小さいことがわかった。なお，本ケースでは， ブロックに $16 \mathrm{t}$ 型を用いた場合の LCCが最小となった。

\section{4. 考察}

地球温暖化の考虑の有無による最適なブロック質量の 違いを検討するために，各検討ケースのハドソン式によ る必要質量に対するLCC 最適となったブロック質量の比 （最適ブロック質量比）を求めた。まず，最適ブロック質 量比と堤前波高との関係を図-8に示す. $8 \mathrm{~m}$ 以下の堤前波 高の場合，必要質量よりも大きなブロックを用いる方が LCCを低滅させることができる。また，辻尾ら（2012） と同様に水深波高比に着目し, 最適ブロック質量比と水 深波高比の関係を調べ，図-9に示す．最適なブロック質 量は，温暖化の考慮の有無によって変わらない場合がほ とんどであるが，水深波高比が 2.0 程度以上の場合， LCC を最小にするには，消波ブロックを大きくする必要があ ることがわかった。これは，辻尾ら（2012）での期待滑 動量や必要堤体幅の増加率と整合する結果であり, 水深 が深く, 設計波が比較的小さい場合に地球温暖化による 安定性低下の影響が大きくなるためと考えられる。

次に，地球温暖化の考慮の有無による $\mathrm{LCC}$ の増加率 （温暖化を考慮した場合の最小 $\mathrm{LCC}$ ／現在気候での最小

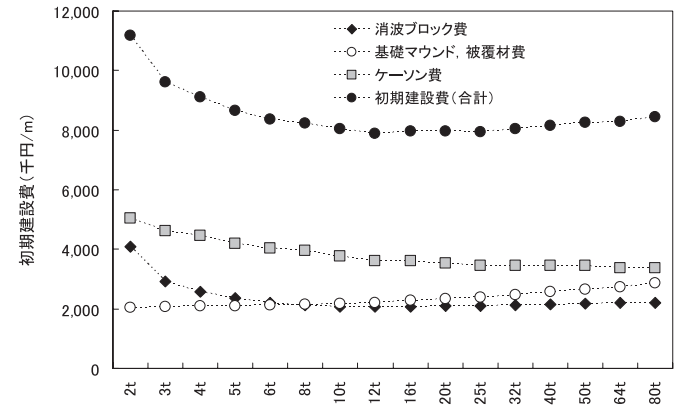

図-5 ブロック質量別の初期建設費の算出例

(領域 II, $K_{r}=0.5, h=7 \mathrm{~m}$ )

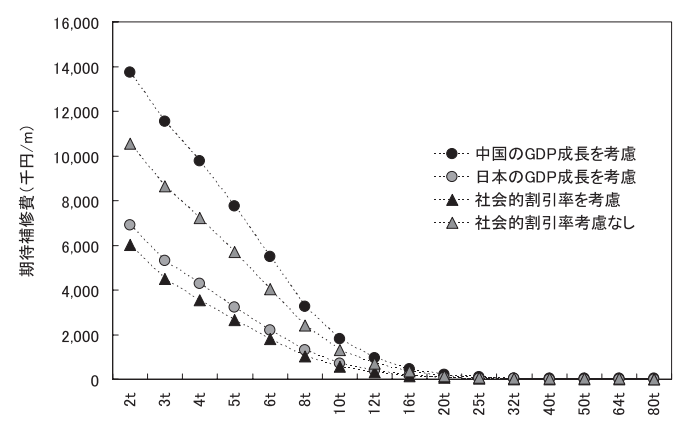

図-6 ブロック質量別の期待補修費の算出例

(領域 II, $K_{r}=0.5, h=7 \mathrm{~m}$, 温暖化考慮)

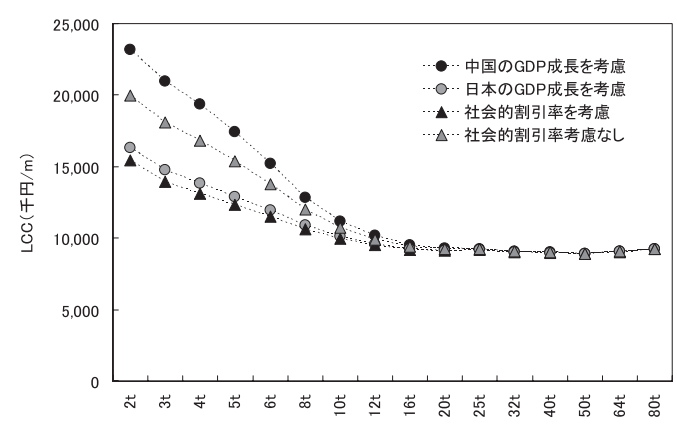

図-7 LCC の算出例（領域 II, $K_{r}=0.5, h=7 \mathrm{~m}$, 温暖化考慮）

LCC）に着目した，LCC増加率と水深波高比の関係を調 べたが，顕著な傾向が得られなかったため，LCC増加率 と堤前波高との関係を調べたものを，図-10に示す，堤前 波高が大きい場合，温暖化による LCC 増加率は $5 \%$ 程度 であるのに対し，堤前波高が小さくなるにつれて増加率 が大きくなり，4m程度では20\%程度の増加率となった。

\section{5. おわりに}

本研究では，消波ブロック被覆堤を対象として，地球 温暖化による沿岸外力の変化を考慮して，最適設計を実 施した．以下に，主要な知見を示す。

1）本検討ケースでは，堤前波高が比較的小さい場合 (ここでは $8 \mathrm{~m}$ 以下), 必要質量よりも大きなブロック 


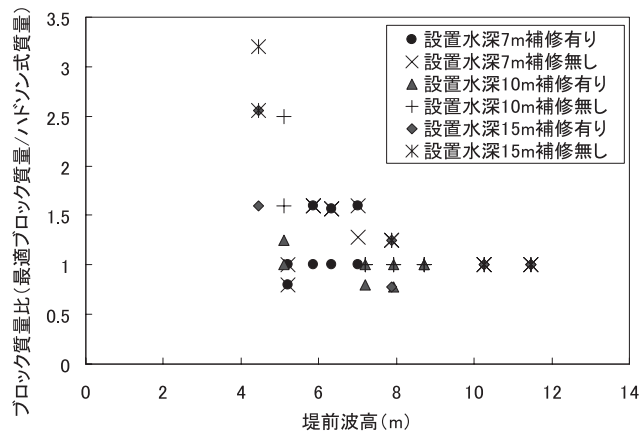

図-8＼cjkstart堤前波高に対する最適ブロック質量比

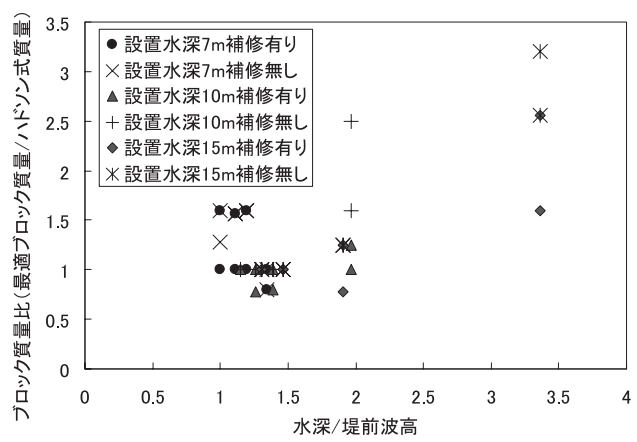

図-9 水深波高比に対する最適ブロック質量比

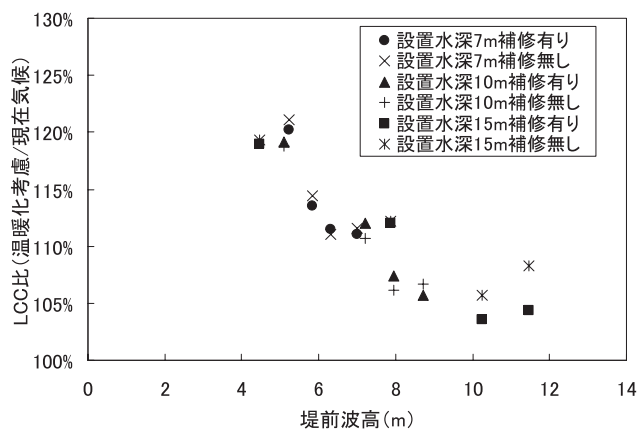

図-10 堤前波高に対するLCC比

を用いることがLCC 最適となる。

2）期待補修費が小さい場合には，社会的割引率や GDP デフレータ等の経済指標による影響は小さい.

3）地球温暖化を考慮すると，堤前波高が小さい場合に， LCCの増加率は大きくなる.

地球温暖化を考慮することで，LCCや最適断面諸元が 変化することから, 今後の防波堤の最適設計には設計供 用期間中の沿岸外力変化を考慮する必要があるとわかっ た.ここに示した解析結果は，将来外力変化をこれまで の知見をもとにして与えた結果である．検討ケースが少 ないことから，一般化できる段階には至っていないが, 今後より確実な外力推定が出てくれば，それらの值を使 うことができ，本方法論は普遍であることを述べておく.
謝辞：本研究を実施するにあたり，（独）港湾空港技術 研究所 河合弘泰 海洋情報研究領域長に高潮の確率偏 差に関する解析結果を提供して頂いた。ここに深謝し ます。また, 本研究は (財) SCOPEの研究助成および The NSFC Major International Joint Research Project (Grant No.51010009）による研究の一部であることを付記し ます。

\section{参 考 文 献}

河合弘泰・橋本典明・松浦邦明（2007）：確率台風モデルを用 いた内湾の高潮の極值と継続時間の推定，海岸工学論文 集, 第 54巻, pp. 301-305.

酒井和彦・岡安章夫（2004）：温暖化による海面上昇を考慮し た防波堤の信頼性設計法，海岸工学論文集，第 51 巻，pp 686-690.

下迫健一郎・高橋重雄（1998）：期待滑動量を用いた混成防波 堤直立部の信頼性設計法，港湾技術研究所報告，第37巻， 第3号, pp. 3-30.

下迫健一郎・大崇菜々子・中野史丈（2006）：滑動量を要求性 能に設定した混成堤の信頼性設計法，港湾空港技術研究 所報告，第 45 巻，第3号, pp. 1-20.

(社) 日本経済研究センター（2007）：長期経済予測（2006～ 2050 年), $147 \mathrm{p}$.

（社）日本港湾協会（2007）：港湾の施設の技術上の基準・同解 説, $1485 \mathrm{p}$.

高山知司・辻尾大樹・安田誠宏（2007）：消波ブロック被覆堤 の変状による波力増大を考慮した期待滑動量算定法の検 討, 海岸工学論文集, 第 54巻, pp. 906-910.

辻尾大樹・安田誠宏（2009）：ライフサイクルコストを考慮し た消波ブロック被覆堤の最適設計に関する研究，土木学 会論文集 B2（海岸工学），Vol. 65, No. 1, pp. 916-920.

辻尾大樹 - 間瀬 肇・森 信人 ·安田誠宏 (2012) : 地球温暖 化による沿岸外力変化を考慮した消波ブロック被覆堤の 滑動量解析，海洋開発論文集，第28巻 (印刷中).

橋本典明・河合泰弘・松浦邦明（2005）：地球温暖化を考慮し た将来の台風特性の解析と確率台風モデルの導入，海岸 工学論文集, 第 52巻, pp. 1221-1225.

森 信人·志村智也 ·安田誠宏 - 間瀬 肇 (2010)：地球温暖 化に伴う極大波高の将来変化予測，土木学会論文集 B2 (海岸工学), Vol. 66, No.1, pp. 1231-1235.

森 信人 · 志村智也 · 中條壮大 · 安田誠宏 · 間瀬 肇 (2011) : マルチモデルアンサンブルに基づく地球温暖化 に伴う沿岸外力の将来変化予測, 土木学会論文集 B2（海 岸工学), Vol.67, pp. I_1191-I_1195.

安田誠宏・中條壮大 ·金 洙列 - 森 信人 ·間瀬 肇・ Kevin Horsburgh (2011)：気候変動予測実験出力を直接用いた高 潮リスクの評価，土木学会論文集 B2（海岸工学)，Vol.67, No.2, pp. I_1171-I_1175.

IPCC AR4 (2007): IPCC fourth assessment report (AR4), http://www.ipcc.ch/.

Kitoh A, Ose T, Kurihara K, Kusunoki S, Sugi M, KAKUSHIN Team-3 Modeling Group. 2009. Projection of changes in future weather extremes using super-high-resolution global and regional atmospheric models in the KAKUSHIN Program: Results of preliminary experiments. Hydrological Research Letters, 3, 49-53. doi:10.3178/hrl.3.49.

Mori, N. (2012): Projection of Future Tropical Cyclone Characteristics based on Statistical Model, In Cyclones Formation, Triggers and Control, Nova Science Publishers, Inc., $24 \mathrm{p}$. 